\title{
Oil and the U.S. Macroeconomy: An Update and a Simple Forecasting Exercise
}

\author{
Kevin L. Kliesen
}

\begin{abstract}
Some analysts and economists recently warned that the U.S. economy faces a much higher risk of recession should the price of oil rise to $\$ 100$ per barrel or more. In February 2008, spot crude oil prices closed above $\$ 100$ per barrel for the first time ever, and since then they have climbed even higher. Meanwhile, according to some surveys of economists, it is highly probable that a recession began in the United States in late 2007 or early 2008. Although the findings in this paper are consistent with the view that the U.S. economy has become much less sensitive to large changes in oil prices, a simple forecasting exercise using Hamilton's model augmented with the first principal component of 85 macroeconomic variables reveals that a permanent increase in the price of crude oil to $\$ 150$ per barrel by the end of 2008 could have a significant negative effect on the growth rate of real gross domestic product in the short run. Moreover, the model also predicts that such an increase in oil prices would produce much higher overall and core inflation rates in 2009 than most policymakers expect. (JEL E37, E66, Q43)
\end{abstract}

Federal Reserve Bank of St. Louis Review, September/October 2008, 90(5), pp. 505-16.

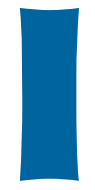

n December 2001, the spot price of West Texas Intermediate (WTI) crude oil averaged $\$ 19.33$ per barrel. Shortly thereafter, oil prices started to trend higher. After a brief decline from $\$ 74$ per barrel in July 2006 to about $\$ 55$ per barrel in January 2007, oil prices then resumed their upward trajectory. They surpassed \$90 per barrel in October 2007. Meanwhile, participants and traders in the crude oil futures market did not foresee the sharp rise in prices. However, some economists and energy analysts correctly expected the price of crude oil to eventually rise to $\$ 100$ per barrel or more, and crude oil prices eventually closed above $\$ 100$ per barrel on February 19 this year for the first time ever. ${ }^{1}$ Some of these analysts also predicted that \$100-per-barrel crude oil would cause the

1 See Greenspan (2007), King and Chazan (2007), and Verleger (2007).
U.S. economy to fall into a recession. Since then, spot WTI prices have risen to more than $\$ 130$ per barrel, and officials from the Organization of the Petroleum Exporting Countries and some financial market participants have recently predicted that oil prices could eventually reach $\$ 200$ per barrel. ${ }^{2}$

Some recent research suggests that the economy responds differently to an oil price shock, depending on the initial prevailing macroeconomic conditions and, moreover, whether the oil price increase is (i) moderate and steady, as occurred from 2003 to 2006, or (ii) rapid and large, as occurred since 2007. Moreover, small timeseries models may capture the aggregate economic effects of large oil price increases over relatively

2 See Hoyos (2008). Alternatively, Brown, Virmani, and Alm (2008) contend that oil prices are not likely to remain above $\$ 100$ per barrel (in 2008 dollars) unless there is a significant supply shock.

Kevin L. Kliesen is an associate economist in the Research Division of the Federal Reserve Bank of St. Louis. The author thanks Cletus C. Coughlin and Yi Wen for comments. Joshua A. Byrge provided research assistance.

(C) 2008, The Federal Reserve Bank of St. Louis. The views expressed in this article are those of the author(s) and do not necessarily reflect the views of the Federal Reserve System, the Board of Governors, or the regional Federal Reserve Banks. Articles may be reprinted, reproduced, published, distributed, displayed, and transmitted in their entirety if copyright notice, author name(s), and full citation are included. Abstracts, synopses, and other derivative works may be made only with prior written permission of the Federal Reserve Bank of St. Louis. 


\section{Figure 1}

\section{Real and Nominal Changes in Spot Oil Prices}

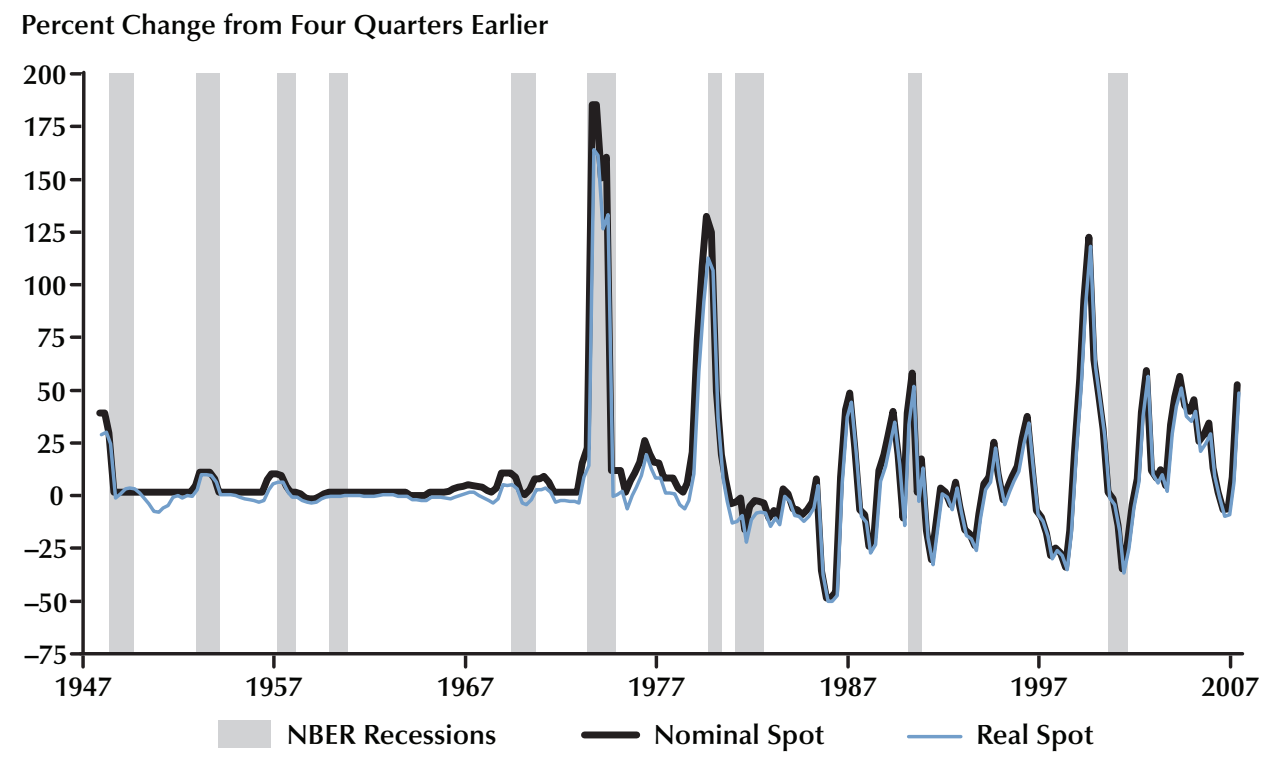

NOTE: NBER, National Bureau of Economic Research.

short periods better than large structural models (Huntington, 2005). Using an augmented model proposed by Hamilton (2003), this article will show that a permanent increase in the spot price of crude oil to either $\$ 100$ or $\$ 150$ per barrel would cause a modest slowing in real GDP growth and its major components relative to a baseline forecast without oil prices. This result could be important given the relatively weak growth over the first half of 2008. Moreover, this model also predicts that an increase in the spot price of crude oil to \$150 per barrel will cause both overall and core inflation rates to rise to 4 percent in 2009. This inflation forecast is well above the expectations of Federal Reserve policymakers in early 2008.

\section{OIL AND MACROECONOMIC ACTIVITY: A SHORT REVIEW}

Figure 1 shows that nearly all post-World War II recessions in the United States were preceded by, or accompanied by, an increase in oil prices. ${ }^{3}$ Accordingly, oil price shocks tend to be viewed with alarm by forecasters, macroeconomists, financial market participants, and public policymakers. ${ }^{4}$ An oil price shock is typically a large, unexpected increase in the relative price of energy that affects the economic decisions of firms and households. ${ }^{5}$ Moreover, higher oil prices engender direct and indirect (second-order) effects that vary in magnitude across time. In the short run, the price elasticities of the supply and demand for oil are likely very low because firms and consumers find it difficult to change their energy consumption habits immediately and new sources of oil or alternative sources of energy are

\footnotetext{
3 The behavior of oil prices was decidedly different before the 1970s. According to Hamilton (1985), changes in U.S. crude oil prices prior to the 1970s were influenced importantly by decisions of the Texas Railroad Commission, a state regulatory agency that actively sought to control the production of Texas crude oil. As a result, domestic oil prices were remarkably stable during this period.

4 See Bernanke (2004).

5 See Jones, Leiby, and Paik (2004) and Hamilton (2005) for a survey of the oil-macroeconomy literature.
} 
not immediately available. Over the longer term, these price elasticities increase. Higher prices not only spur producers to seek new sources of crude oil, but also provide important incentives to conserve energy and increase the production of alternative energy sources.

An oil price increase may lower real gross domestic product (GDP) growth through other channels. First, higher prices raise uncertainty about future oil prices and thus cause delays in business investment (e.g., Bernanke, 1983, and Pindyck, 1991). Guo and Kliesen (2005), for example, find that increased oil price volatility from 1984 to 2004 had a significant effect on key measures of U.S. macroeconomic activity, such as business capital spending. Second, oil price changes induce resource reallocation, and such reallocation is costly (e.g., Lilien, 1982, Davis and Haltiwanger, 2001, and Lee and Ni, 2002). Not surprisingly, the large, sustained increase in oil prices since 2007 that has pushed the national average price of gasoline past $\$ 4$ per gallon has precipitated some potentially long-term resource reallocation in the automotive industry. Currently, automotive manufacturers are actively engaged in the design and production of hybrid vehicles or vehicles that run on biofuels or alternative fuels, such as hydrogen. This entails various changes: for example, the design of new components, including lithium batteries and drive trains, and the training of automotive technicians accustomed to working solely on internal combustion engines.

The link between oil price changes and economic activity is complicated by other factors, such as economic growth and the influence of domestic monetary policymakers. ${ }^{6}$ For example, Huntington (2005) argues that oil price shocks that occur after a period of low inflation and low interest rates are less likely to cause a recession or a significant slowing of real GDP than if the prior economic conditions were high inflation and high interest rates. According to Barsky and Kilian (2004), the link between higher oil prices and weaker economic growth is complicated by the endogeneity of oil prices. This view holds

6 Regarding the latter, see, among others, Bernanke et al. (1997), Leduc and Sill (2004), and Hamilton and Herrera (2004). that demand shocks, rather than supply shocks, have been the dominant factors explaining higher oil prices. In a similar vein, Aguiar-Conraria and Wen (2007) study the demand channel of oil shocks during the 1970s.

Estimates of the short-run macroeconomic effects of higher oil prices on real GDP growth vary. According to a 2005 survey of several macroeconomic models reported by Huntington, a \$10per-barrel increase in the price of oil is expected to reduce output in the United States by about 0.25 percentage points in the first year and about 0.5 percentage points in the second year (relative to a baseline forecast). ${ }^{7}$ A study published by the International Monetary Fund (IMF) in December 2000 (Robinson et al.) showed that a permanent $\$ 5$-per-barrel increase in the price of oil would reduce world real GDP growth by about 0.25 percentage points per year over the first four years; the effect on U.S. real GDP growth over the same period was slightly larger than 0.3 percentage points per year. ${ }^{8}$ Similar results were found for models used by the Federal Reserve (MULTIMOD), the Organisation for Economic Co-operation and Development (INTERLINK), and the Brookings Institution (McKibbin-Sachs Global model).

\section{The Effects of Oil Price Changes on Output and Inflation Since 1970}

A rough approximation of the potential effects of higher oil prices on real GDP growth and inflation can be derived with the simple model used by Hamilton (2003):

(1) $\Delta \ln \left(y_{t}\right)=\alpha+\sum_{i=1}^{4}\left[\beta_{i} \Delta \ln \left(y_{t-i}\right)+\delta_{i} \Delta \ln \left(x_{t-i}\right)\right]+e_{t}$.

In this analysis, $y_{t}$ is a measure of the log change in real GDP at an annual rate. ${ }^{9}$ The oil

7 These models assume a constant price elasticity in the short term because of the limited ability to substitute away from oil as an energy source.

8 The IMF used the average price of Brent (United Kingdom), Dubai, and WTI grades. In November 2000, this reference price averaged about $\$ 32$ per barrel according to the IMF.

9 Hamilton originally used the log change in real GDP at a quarterly rate. 
price change, $X_{t}$, is the price of crude oil transformed according to Hamilton (2003). ${ }^{10}$ Hamilton showed that an asymmetric measure of oil prices helps explain real GDP growth. He also showed that the sum of the coefficients on the lagged values of the net oil price (NOP) measure was highly significant, even though some of the individual coefficients were not. Hamilton's measure of the NOP is constructed as follows: The currentquarter price of oil is compared with the maximum price over the previous 12 quarters. If the percentage difference is positive, that observation is used; but if the percentage difference is negative, that month's observation is set to zero. For example, in the fourth quarter of 2007 (December 2007), the spot price of WTI crude oil was $\$ 91.73$ per barrel. Over the previous 12 quarters (2004:Q4-2007:Q3), the maximum crude oil price was $\$ 79.93$ per barrel, a difference of 14.8 percent. If the price of WTI was \$79.93 per barrel or less in 2007:Q4 (producing a zero or negative percentage change), the observation for that quarter would have been set to equal zero. Thus, in the Hamilton framework, only energy price increases matter; energy price decreases do not matter.

Table 1 shows regression results of the above equation and three alternative specifications. The sample period is 1970:Q1-2007:Q4. The analysis begins in 1970:Q1 because, as is evident from the discussion of Figure 1, oil prices were relatively stable before 1970. Accordingly, a large percentage of observations for the Hamilton NOP variable are zeroes before 1970. Second, all of the major oil price shocks have occurred since 1973.

Regression (1) in Table 1 reports results from a model that predicts future real GDP growth using lagged growth rates. Although this simple AR(4) model is commonly used to predict future GDP growth, the adjusted $R^{2}$ is quite low, 0.06 . Regression (2) is equivalent to equation (1) at the beginning of this section. Adding the NOP variable doubles the explanatory power of the model, as the adjusted $R^{2}$ rises to 0.12 . Interestingly, adding

\footnotetext{
10 This analysis uses the spot price of WTI crude oil. Hamilton (2003) used the producer price index for crude petroleum. The quarterly value is not the average of the monthly observations (e.g., January, February, and March), but instead it is the last month of the quarter (March, June, September, December).
}

the NOP variable renders insignificant the first and second lags of real GDP growth, which were significant in regression (1).

In Table 1, regressions (3) and (4) extend Hamilton's model by adding the Chicago Fed National Activity Index (CFNAI), $z_{t}$ :

(2)

$$
\begin{aligned}
& \Delta \ln \left(y_{t}\right)=\alpha+\sum_{i=1}^{4}\left[\beta_{i} \Delta \ln \left(y_{t-i}\right)+\delta_{i} \Delta \ln \left(x_{t-i}\right)\right] \\
& +\sum_{i=0}^{1} \gamma_{i} z_{t-i}+e_{t} .
\end{aligned}
$$

The CFNAI is the first principal component, or common factor, of 85 monthly indicators of real economic activity. ${ }^{11}$ Much empirical research has shown that principal components can significantly improve the forecasting performance of major macroeconomic variables such as real GDP growth and inflation. ${ }^{12}$ This result is reinforced in regressions (3) and (4) in Table 1. Adding the contemporaneous and lagged value of the CFNAI $\left(z_{t}\right.$ and $z_{t-1}$ ) to both the AR(4) model and Hamilton's equation (equation (2)) shows that the CFNAI is highly significant. ${ }^{13}$ In addition, the first and second lags of NOP are now also highly significant. As a result, the explanatory power of regressions (3) and (4) is significantly larger than for regressions (1) and (2). Adding the CFNAI reduces the sum of the NOP coefficients from -0.19 in regression (2) to -0.09 in regression (4).

A further extension of Hamilton's analysis can be seen in Table 2. In this case, the analysis examines whether the NOP variable helps to predict the growth of real GDP-and, separately, its major components-and inflation (log change) using four separate price measures. The inflation series are based on the overall price indices measured by the consumer price index (CPI) and the

\footnotetext{
11 See the "CFNAI Background Release" (www.chicagofed.org/ economic_research_and_data/files/cfnai_background.pdf) and "CFNAI Technical Report” (www.chicagofed.org/economic research_and_data/files/cfnai_technical_report.pdf) on the Federal Reserve Bank of Chicago web site.

12 See Gavin and Kliesen (2008) and references cited therein.

13 The second, third, and fourth lags of CFNAI were dropped because they were not significant.
} 


\section{Table 1}

\section{Predicting Real GDP Growth $\left(y_{t}\right)$ Using Lagged Real GDP Growth, Oil Prices $\left(x_{t}\right)$, and the} Chicago Fed National Activity Index, $z_{t}$

\begin{tabular}{lcccc} 
& $(\mathbf{1})$ & $\mathbf{( 2 )}$ & $\mathbf{( 3 )}$ & $\mathbf{( 4 )}$ \\
\hline Constant & $1.90^{* * *}$ & $2.91^{* * *}$ & $4.84^{* * *}$ & $5.33^{* * *}$ \\
& $(0.45)$ & $(0.52)$ & $(0.45)$ & $(0.48)$ \\
$y_{t-1}$ & $0.22^{* * *}$ & 0.14 & $-0.26^{* * *}$ & $-0.31^{* * *}$ \\
& $(0.08)$ & $(0.08)$ & $(0.08)$ & $(0.08)$ \\
$y_{t-2}$ & $0.14^{*}$ & 0.08 & $-0.13^{* *}$ & $-0.15^{* *}$ \\
& $(0.08)$ & $(0.08)$ & $(0.06)$ & $(0.06)$ \\
$y_{t-3}$ & 0.00 & -0.01 & $-0.17^{* * *}$ & $-0.16^{* * *}$ \\
& $(0.08)$ & $(0.08)$ & $(0.06)$ & $(0.06)$ \\
$y_{t-4}$ & 0.01 & 0.00 & -0.06 & -0.06 \\
& $(0.08)$ & $(0.08)$ & $(0.06)$ & $(0.06)$ \\
$x_{t-1}$ & & -0.04 & & $-0.04^{* *}$ \\
& & $(0.03)$ & & $(0.02)$ \\
$x_{t-2}$ & & $-0.07^{* *}$ & $-0.06^{* * *}$ \\
$x_{t-3}$ & $(0.03)$ & & $(0.02)$ \\
$x_{t-4}$ & -0.03 & & 0.01 \\
& & $(0.03)$ & & $(0.02)$ \\
$z_{t}$ & & $-0.05^{*}$ & & 0.00 \\
& & $(0.03)$ & & $(0.02)$ \\
$z_{t-1}$ & & & $2.48^{* * *}$ \\
Adj. $R^{2}$ & & & $(0.29)$ \\
DW & & & $1.53^{* * *}$ \\
& & 0.12 & $(0.28)$ & $(0.40)$ \\
& & 2.00 & $1.33^{* * *}$ & 0.58 \\
& & & $(0.40)$ & 2.03
\end{tabular}

NOTE: ${ }^{* * *}, * *$, and $*$ denote significance at the 1,5 , and 10 percent levels, respectively. DW, Durbin-Watson. The sample period is 1970:Q1-2007:Q4. Standard errors are shown in parentheses.

personal consumption expenditures (PCE) price index (PCEPI), as well as their respective "core" measures that exclude food and energy prices. The empirical results reported in Table 2 are based on equation (2) above. However, instead of reporting each of the coefficients (and their statistical significance) of the independent variables (including the CFNAI terms), Table 2 reports only the sum of the coefficients on the lagged NOP terms for each expenditure category. The GDP expenditure categories and price variables thus become, separately, the $y_{t}$ terms. Each row in Table 2 also shows an $F$-statistic to determine the significance of the sum of the coefficients on
NOP variables. In addition to the entire sample period (from 1970:Q1-2007:Q4), Table 2 also shows results for three subperiods: 1970:Q1-1982:Q4, 1983:Q1-1994:Q4, and 1995:Q1-2007:Q4. The partition of the second and third periods reflects, respectively, the onset of the Great Moderation and the acceleration in trend productivity growth. ${ }^{14}$

Effects on Output. Table 2 shows that energy price increases significantly help to predict real GDP growth and most of its components. However, the size of this effect varies across

\footnotetext{
${ }^{14}$ See Anderson and Kliesen (2006).
} 


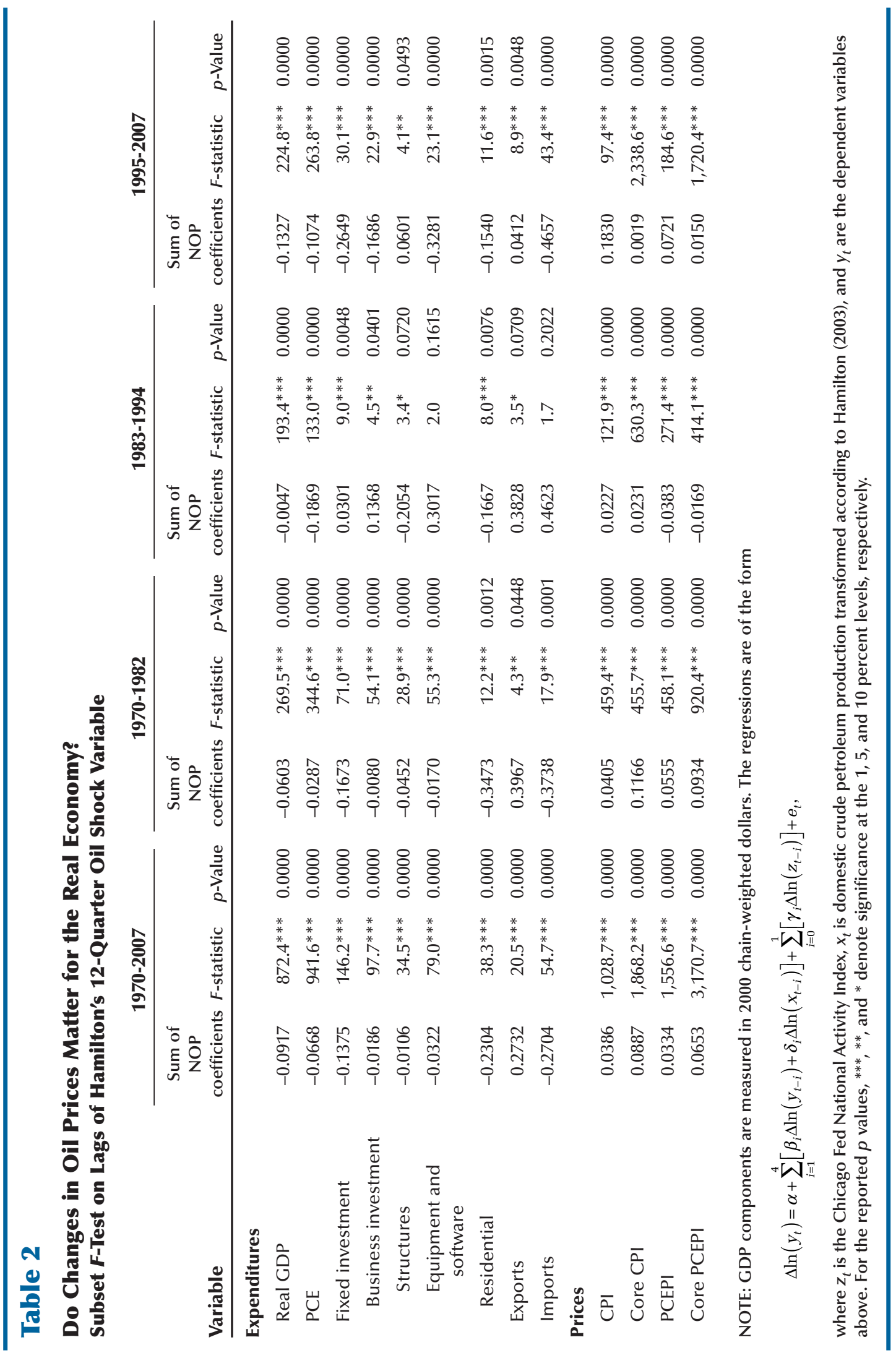


indicators and across time. Over the entire sample period the sum of the energy coefficients on real GDP growth was highly significant, though modest (-0.09). The first row of Table 2 indicates that the oil price increases had their largest effect on real GDP growth $(-0.13)$ over the final period. This is perhaps surprising, given the acceleration in productivity growth and the continued drop in energy usage per unit of GDP. This result may reflect the relatively sharp, unexpected increase in energy prices that have occurred since then. The effects of energy price increases on real GDP growth were much smaller during the Great Inflation period $(-0.06)$. The effects of higher energy prices on real GDP growth were even smaller in the subsequent period $(-0.005)$.

Table 2 reveals other interesting findings. First, during the Great Inflation, the largest (negative) effects of oil price increases were on real residential fixed investment and imports; however, the effect on real consumer spending (PCE) was relatively small during this period. Second, the smallest effect of oil price increases on the components of real GDP occurred from 1983 to 1994. The notable exception was real consumer spending. During this period (1983-94), the sum of the NOP coefficients was -0.19, substantially larger than both the previous and following periods. Moreover, in the cases of real fixed investment in business equipment and software and real imports, the sign not only became positive during the 1983-94 period, but the significance of oil price increases disappeared altogether. Third, since 1995, the sensitivity of real equipment and software investment has increased significantly. This is consistent with the literature reports cited earlier, in which increasing oil prices had a sizable influence on business capital spending. In fact, the coefficient is about equal in magnitude to that of the second period, but the sign is changed. In addition, higher oil prices now help to predict business investment in structures. However, this change could reflect the fact that the share of nominal fixed investment in drilling and mining activity as a percent of nominal nonresidential fixed investment increased from about 1.75 percent in 1995 to 8 percent in 2007. Finally, although the effect of oil price increases on real
PCE since 1995 has diminished somewhat compared with the 1983-94 period (from -0.19 to -0.11 ), the sum of the coefficients is more significant compared with the 1970-82 period.

Effects on Consumer Price Inflation. The last four rows of Table 2 show the results of equation (2) as applied to the four price series previously mentioned. ${ }^{15}$ Since 1970 , the sum of the coefficients on oil price increases, which have the expected positive sign and are highly significant, are essentially the same for both the total CPI and the total PCEPI (0.04). The sums of the coefficients on the core price indices are also roughly equal to each other, but the sums of the coefficients are larger, and even more significant, than for the total price measures. It appears that the latter effect stems from the Great Inflation period. Since 1983, the effects of higher oil prices on core inflation have been much more modest and considerably smaller than those on the total price measures. The results in Table 2 provide some evidence for the decision by the Federal Open Market Committee to place somewhat more emphasis on core PCEPI inflation during the run-up in oil prices over the past several years.

\section{A Simple Forecasting Exercise}

Results from Tables 1 and 2 suggest that past oil price increases are statistically significant predictors of economic activity and inflation in the current quarter. This section provides some evidence that Hamilton's NOP variable helps to forecast the growth of economic activity and inflation one quarter ahead. In this experiment, the baseline forecast uses an AR(4) model augmented with the CFNAI; this is a one-periodahead version of regression (3) in Table 1-that is, excluding oil prices. The unrestricted model adds Hamilton's NOP series as an explanatory

\footnotetext{
${ }^{15}$ A version of Table 1 was estimated for the PCEPI and core PCEPI series. That is, inflation was regressed on (i) four lags of inflation, (ii) four lags of Hamilton's NOP measure, and (iii) the contemporaneous and lagged value of the CFNAI. In results not published here, the adjusted $R^{2}$ for PCEPI inflation in (i) is 0.76. Adding the CFNAI increased the adjusted $R^{2}$ to 0.78 ; the adjusted $R^{2}$ for the AR(4) for core PCEPI is 0.82; and adding the CFNAI boosted the adjusted $R^{2}$ to 0.83 . Adding Hamilton's NOP to the latter model raised adjusted $R^{2}$ to 0.86 . These results are available on request.
} 
Table 3

Evaluating Forecasts With and Without Oil Price Increases

\begin{tabular}{|c|c|c|c|}
\hline Variable & Base & $+W T I$ & + PPI \\
\hline \multicolumn{4}{|l|}{ Expenditures } \\
\hline Real GDP & 1.60 & 1.56 & 1.57 \\
\hline PCE & 1.55 & 1.41 & 1.47 \\
\hline Fixed investment & 5.21 & 5.28 & 5.38 \\
\hline Business investment & 5.60 & 5.69 & 5.94 \\
\hline Structures & 8.83 & 8.86 & 9.45 \\
\hline Equipment and software & 5.98 & 6.00 & 6.05 \\
\hline Residential & 9.27 & 9.48 & 10.03 \\
\hline Exports & 7.13 & 7.35 & 7.30 \\
\hline Imports & 5.31 & 4.69 & 4.96 \\
\hline \multicolumn{4}{|l|}{ Prices } \\
\hline CPI & 2.03 & 2.01 & 2.03 \\
\hline Core CPI & 0.63 & 0.81 & 0.91 \\
\hline PCEPI & 1.47 & 1.46 & 1.48 \\
\hline Core PCEPI & 0.51 & 0.61 & 0.59 \\
\hline
\end{tabular}

NOTE: Data are presented as root mean square forecast errors in percent. The base forecast is an AR(4) model augmented with the contemporaneous and first lag of the CFNAI. The alternative models are augmented with either the spot price of West Texas Intermediate (WTI) or the PPI for domestic crude petroleum production. Both oil prices are transformed according to Hamilton (2003). The augmented model is regression (4) from Table 1. The base and alternative models are estimated for the period 1970:Q1-2001:Q4. Then, one-stepahead pseudo-forecasts are estimated for 2002:Q1-2007:Q4. Forecast errors in bold indicate that the forecast errors from the augmented model are significantly different from the base model according to the Clark-McCracken test.

variable (regression (4) in Table 1). The analysis continues to use the spot price of WTI as before, but now includes the producer price index (PPI) for domestic crude petroleum as an alternative measure of oil prices. ${ }^{16}$ Again, each of these oil price series is modified according to the Hamilton specification. First, the restricted model (without energy) is estimated from 1970:Q1 to 2001:Q4. The model is estimated for each of the output and price series listed in Table 2. Next, one-stepahead pseudo-out-of-sample forecasts (with and without energy) are computed from 2002:Q1 to 2007:Q4. Table 3 presents the root mean square errors (RMSEs) from this forecasting exercise.

The value of any forecast to the practitioner or the policymaker is its accuracy. A standard test of forecast accuracy is the one proposed by

${ }^{16}$ The PPI series is the oil price series used in Hamilton's analysis.
Diebold and Mariano (1995; DM). However, as Clark and McCracken (2001; CM) point out, the DM test is not appropriate for nested models such as those used here. In Table 3, the null hypothesis is that the baseline forecasts (without NOP) and the augmented forecast (with NOP) have the same predictive power. Based on the CM test statistic, Table 3 shows that spot oil price increases can help improve the baseline, one-quarter-ahead forecast for the growth of real GDP, real PCE, and real imports. However, this is not the case for the PPI measure of oil prices. In all other series listed in Table 3, the PPI measure of oil prices-which is the series Hamilton used-does not improve the baseline forecast. However, Table 3 shows that adding the WTI spot oil price increase to the price equations marginally improves the RMSEs of the forecasts for overall CPI and PCE inflation. For example, adding the spot WTI to the CPI 
inflation forecasting equation reduces the RMSE from 2.03 (baseline) to 2.01. Notably, the RMSE for the PCEPI inflation forecasts are much smaller than those for the CPI series.

Alternative scenarios of economic growth and inflation over the near term matter most for conducting monetary policy. Accordingly, the analysis is now extended to gauge the potential effects of higher oil prices on economic growth and inflation in 2008 and 2009. First, the model for each variable is estimated for the 1970:Q1-2007:Q4 period. Next, the model is used to forecast out-ofsample growth rates for the 2008:Q1-2009:Q4 period. The baseline forecast is the same AR(4) model augmented with the CFNAI. ${ }^{17}$ The baseline forecast is augmented with two separate scenarios for the spot price of WTI to gauge the effects of higher oil prices through 2009. In the first scenario, the spot price of WTI averages $\$ 100$ per barrel for the four quarters of 2008 and remains at that level through 2009:Q4. In the second scenario, the spot price of WTI increases from $\$ 100$ per barrel in 2008:Q1 to $\$ 150$ per barrel in 2009:Q1 and then remains at that level until 2009:Q4. ${ }^{18}$ Finally, these forecasts are compared with the forecasts released by the Federal Reserve Bank of Philadelphia's Survey of Professional Forecasters (SPF) on February 12, 2008. One drawback to the $\mathrm{SPF}$ is that the quarterly forecast horizon extends only to 2009:Q1.

Huntington (2005), in a study that compares different types of macroeconomic models, argues that small time-series models may capture the aggregate economic effects of large oil price increases that occur over relatively short periodslike those that have occurred since 2007. He argues that structural models are better able to capture the economic impacts of a gradual increase in oil prices. Table 4 shows out-of-sample forecasts using Hamilton's augmented model. Forecasted annual average growth rates for 2008 and 2009 are shown for real GDP, real PCE, real business fixed investment, and PCEPI and core PCEPI

\footnotetext{
${ }^{17}$ An AR(4) model is used to estimate the out-of-sample values for the CFNAI.

${ }^{18}$ Spot WTI is assumed to rise 10.75 percent per quarter from 2008:Q1 to 2009:Q1, reaching a level of \$150.44 per barrel.
}

inflation. ${ }^{19}$ As shown, the baseline forecast for real GDP growth in 2008 (2.4 percent) is modestly more optimistic than the SPF forecast (1.9 percent). The baseline forecast incorporating the assumption of $\$ 100$ per barrel oil in 2008-a modest step up from its average of $\$ 91.73$ per barrel in the fourth quarter of 2007-lowers the forecast for real GDP growth in 2008 by slightly less than 0.25 percentage points to about 2.25 percent. ${ }^{20}$

Table 4 suggests that an additional \$50-perbarrel increase in oil prices reduces the forecast for real GDP growth in 2008 by about another 0.25 percentage points, so that \$150-per-barrel oil cuts the forecast for real GDP growth in 2008 by 0.5 percentage points from its baseline forecast (2.4 percent). The model thus predicts that each $\$ 10$ per-barrel permanent increase in spot oil prices reduces real GDP growth by 0.1 percentage points within one year, and even less after two years. Recall that Huntington (2005) found that each \$10-per-barrel increase in crude oil reduced real GDP growth by about 0.25 percentage points.

For 2009, the baseline model predicts that real GDP will increase 3.1 percent. ${ }^{21}$ The predicted growth for real GDP in 2009 with either of the two oil price scenarios differs little from the baseline forecast. In either case, the unrestricted Hamilton model does not predict long-lasting effects on real GDP growth from an increase in oil prices. Hence, once oil prices stabilize, and the drag from higher oil prices ends, the model predicts that real GDP will converge to trend-like growth relatively quickly. This is a common characteristic of most forecasting models.

Forecasts for the remaining variables in Table 4 are generally consistent with the findings from Tables 2 and 3: Higher oil prices have their largest effects on real consumer expenditures. In

\footnotetext{
19 The data series were last updated on February 28, 2008.

${ }^{20}$ Growth rates for the year are forecast averages for the four quarters of each year.

${ }^{21}$ The February 10, 2008, Blue Chip Economic Indicators reported that the Blue Chip Consensus predicts that real GDP would increase by 2.6 percent in 2009. A consensus forecast published by the National Association for Business Economics on February 25,2008 , predicted that real GDP would increase by 2.9 percent in 2009 .
} 
Table 4

\section{Forecasts of Real Output and Expenditure Growth and Price Inflation Averages of Quarterly Data at Annual Rates}

\begin{tabular}{lccc} 
Indicator & $\mathbf{2 0 0 7}$ & $\mathbf{2 0 0 8}$ & $\mathbf{2 0 0 9}$ \\
\hline Real GDP & (Actual) & & NA \\
SPF & 2.5 & 1.9 & 3.1 \\
Baseline & & 2.4 & 3.2 \\
Baseline $+\$ 100$ oil & & 2.2 & 3.0 \\
Baseline $+\$ 150$ oil & & 1.9 & NA \\
Real PCE & 2.5 & & 3.4 \\
SPF & & 1.9 & 3.6 \\
Baseline & & 3.1 & 3.0 \\
Baseline $+\$ 100$ oil & & 2.8 & NA \\
Baseline $+\$ 150$ oil & & 2.6 & 4.4 \\
Business fixed investment & 7.3 & & 4.5 \\
SPF & & 2.1 & 4.4 \\
Baseline & & 2.7 & \\
Baseline $+\$ 100$ oil & & 2.7 & NA \\
Baseline $+\$ 150$ oil & & 2.5 & 3.2 \\
PCEPI & 3.4 & & 3.3 \\
SPF & & 2.5 & 4.0 \\
Baseline & & 3.2 & NA \\
Baseline $+\$ 100$ oil & & 3.6 & 2.5 \\
Baseline $+\$ 150$ oil & & 3.7 & 4.7 \\
Core PCEPI & & & 2.1 \\
SPF & 2.1 & 2.3 & 3.0 \\
Baseline & & 3.3 & \\
Baseline $+\$ 100$ oil & & & \\
Baseline $+\$ 150$ oil & & &
\end{tabular}

NOTE: The baseline forecast is an AR(4) plus the CFNAI. The forecast horizon for the Survey of Professional Forecasters is 2008:Q1-2009:Q1.

2008, \$100-per-barrel oil is predicted to reduce the growth of real PCE by 0.3 percentage points, while an increase to $\$ 150$ per barrel produces an additional decline of about 0.25 percentage points relative to the baseline forecast. Comparing the baseline forecast for real PCE growth in 2009 with the forecast that assumes \$150-per-barrel oil suggests that higher oil prices will have modestly more persistent negative effects on real consumption spending: 3.4 percent (baseline) versus 3.0 percent ( $\$ 150$ per barrel) than on real GDP growth. Table 4 also suggests that higher oil prices will have considerably more modest short-run effects on business capital spending (business fixed investment), but the effects will not be as persistent as predicted for real consumer spending. Nevertheless, these results are generally, but perhaps weakly, consistent with the literature that finds significant negative effects on business capital spending from higher oil prices.

Perhaps the most interesting findings are those associated with the inflation forecasts. First, 
the baseline forecasts predict modestly higher overall and core inflation for 2008 than does the SPF forecast. Second, the model predicts a considerable acceleration in PCEPI inflation rates in 2008 and 2009 should oil prices increase to $\$ 100$ or $\$ 150$ per barrel. Perhaps most worrisome is that the augmented Hamilton model predicts that a permanent increase in crude oil prices to $\$ 150$ per barrel will lead to overall and core inflation rates of 4 percent (or slightly above) in 2009. If this model is correct, the prospect of crude oil prices rising to $\$ 150$ per barrel could produce a significant acceleration in inflation in 2009.

\section{CONCLUSION}

The analysis in this paper has used a version of Hamilton's model to gauge the effects of higher oil prices on real GDP growth and inflation. One finding of this study is that the model's explanatory power is dramatically improved by adding the Chicago Fed National Activity Index as an explanatory variable. This addition, however, does not diminish another finding-consistent with those in the literature-that oil price increases do matter. Second, oil prices matter more for some GDP components than others, such as real consumer spending. The model also predicts significantly negative effects on business capital spending. Moreover, this sensitivity seems to have increased considerably since 1995 compared with the period from 1970 to 1995.

To gauge the predictive power of these findings, a simple forecasting exercise using Hamilton's model augmented with the CFNAI shows that the estimated negative effects of $\$ 100$ per-barrel oil on real GDP growth are significant but would wane by the end of 2008. An additional \$50-per-barrel increase in the price of crude oil would cut real GDP growth by about 0.25 percentage points in 2008 , but by only 0.1 percentage points in 2009 (both relative to a baseline forecast that excludes oil prices). Statistically, real consumption expenditures would experience similarly large but more persistent negative growth. The augmented Hamilton model predicts much more modest—and less persistent-effects on the growth of real business fixed investment. Finally, the model predicts that a permanent increase in crude oil prices to $\$ 150$ per barrel would cause overall and core PCEPI inflation to rise to 4 percent in 2009. This result, if correct, suggests that policymakers may need to be quite vigilant should oil prices rise to limits heretofore thought unlikely by most analysts.

\section{REFERENCES}

Aguiar-Conraria, Luis and Wen, Yi. "Understanding the Large Negative Impact of Oil Shocks." Journal of Money, Credit, and Banking, June 2007, 39(4), pp. 925-44.

Anderson, Richard G. and Kliesen, Kevin L. "The 1990s Acceleration in Labor Productivity: Causes and Measurement." Federal Reserve Bank of St. Louis Review, May/June 2006, 88(3), pp. 181-202.

Barsky, Robert B. and Kilian, Lutz. "Oil and the Macroeconomy Since the 1970s." Journal of Economic Perspectives, Fall 2004, 18(4), pp. 115-34.

Bernanke, Ben S. "Irreversibility, Uncertainty, and Cyclical Investment." Quarterly Journal of Economics, February 1983, 98(1), pp. 85-106.

Bernanke, Ben S. "Oil and the Macroeconomy." Remarks at the Distinguished Lecture Series, Darton College, Albany, GA, October 21, 2004.

Bernanke, Ben S; Gertler, Mark; Watson, Mark; Sims, Christopher A. and Friedman, Benjamin. "Systematic Monetary Policy and the Effects of Oil Price Shocks." Brookings Papers on Economic Activity, 1997, (1) pp. 91-157.

Brown, Stephen P.A.; Virmani, Raghav and Alm, Richard. "Crude Awakening: Behind the Surge in Oil Prices." Federal Reserve Bank of Dallas

Economic Letter, May 2008, 3(5), pp. 1-8.

Clark, Todd E. and McCracken, Michael W. "Tests of Equal Forecast Accuracy and Encompassing for Nested Models," Journal of Econometrics, November 2001, 105(1), pp. 85-110. 
Davis, Steven J. and Haltiwanger, John. "Sectoral Job Creation and Destruction Responses to Oil Price Changes." Journal of Monetary Economics, December 2001, 48(3), pp. 465-512.

Diebold, Francis X. and Mariano, Roberto S. "Comparing Predictive Accuracy." Journal of Business and Economic Statistics, July 1995, 13(3), pp. 253-63.

Gavin, William T. and Kliesen, Kevin L. "Forecasting Inflation and Output: Comparing Data-Rich Models with Simple Rules." Federal Reserve Bank of St. Louis Review, May/June 2008, 90(3, Part 1), pp. 175-92.

Greenspan, Alan. The Age of Turbulence: Adventures in a New World. New York: Penguin Press, 2007.

Guo, Hui and Kliesen, Kevin L. "Oil Price Volatility and U.S. Macroeconomic Activity.” Federal Reserve Bank of St. Louis Review, November/December 2005, 87(6), pp. 669-83.

Hamilton, James D. "Historical Causes of Postwar Oil Shocks and Recessions.” The Energy Journal, January 1985, 6(1), pp. 97-116.

Hamilton, James D. "What Is an Oil Shock?” Journal of Econometrics, April 2003, 113(2), pp. 363-98.

Hamilton, James D. "Oil and the Macroeconomy," prepared for The New Palgrave Dictionary of Economics, August 24, 2005.

Hamilton, James D. and Herrera, Ana Maria. "Oil Shocks and Aggregate Macroeconomic Behavior: The Role of Monetary Policy." Journal of Money, Credit, and Banking, 2004, 36(2), pp. 265-86.

Hoyos, Carola. “Opec Chief Warns Oil Could Hit \$200 a Barrel.” Financial Times, April 29, 2008, p. 2.
Huntington, Hillard G. "The Economic Consequences of Higher Crude Oil Prices.” Final Report, Energy Modeling Forum, Special Report 9, Stanford University, October 3, 2005.

Jones, Donald W.; Leiby, Paul N. and Paik, Inja K. "Oil Price Shocks and the Macroeconomy: What Has Been Learned Since 1996?” Energy Journal, April 1, 2004, 25(2), pp. 1-32.

King, Neil Jr. and Chazan, Guy. "Why Oil May Not Stop at \$100.” Wall Street Journal, October 31, 2007, p. A6.

Leduc, Sylvain and Sill, Keith. "A Quantitative Analysis of Oil Price Shocks, Systematic Monetary Policy, and Economic Downturns." Journal of Monetary Economics, May 2004, 51(4), pp. 781-808.

Lee, Kiseok and Ni, Shawn. "On the Dynamic Effects of Oil Price Shocks: A Study Using Industry Level Data." Journal of Monetary Economics, May 2002, 49(4), pp. 823-52.

Lilien, David. M. "Sectoral Shifts and Cyclical Unemployment.” Journal of Political Economy, August 1982, 90(4), pp. 777-93.

Pindyck, Robert. "Irreversibility, Uncertainty, and Investment.” Journal of Economic Literature, September 1991, 29(3), pp. 110-48.

Robinson, David; Bayoumi, Tamim; Kumar, Manmohan S.; Isard, Peter; MacFarlan, Maitland; Edison, Hali; Rourke, Blair; Hunt, Benjamin and Cheetham, Ximena. "The Impact of Higher Oil Prices on the Global Economy." Washington, DC: International Monetary Fund, December 8, 2000.

Verleger, Philip K. Jr. "The Coming Triple-Digit Oil Prices.” International Economy, Fall 2007, pp. 52-56. 